\title{
Phytosociological study of a riverine forest remnant from Taquari river, State of Rio Grande do Sul, Brazil
}

\author{
Fabiane Lucheta ${ }^{1,5}$, Gabriel Nicolini², Gerson Luiz Ely Junior ${ }^{2}$, Marilaine Tremarin ${ }^{2}$, Marelise Teixeira ${ }^{2}$, \\ Úrsula Arend ${ }^{3}$, Natália Mossmann $\mathrm{Koch}^{4}$ and Elisete Maria de Freitas ${ }^{2}$
}

Received: 19.10.2017; accepted: 1.02 .2018

\begin{abstract}
Phytosociological study of a riverine forest remnant from Taquari river, State of Rio Grande do Sul, Brazil). Aiming to characterize the structure of the arboreal community in a riverine forest remnant of the Taquari river, State of Rio Grande do Sul, 42 sampling units of $100 \mathrm{~m}^{2}(10 \times 10 \mathrm{~m})$ were located. Phytosociological parameters were also assessed and the indexes of Shannon diversity $\left(\mathrm{H}^{\prime}\right)$ and Pielou evenness (J) were evaluated. A total of 39 species, 21 families, 2.83 nats ind ${ }^{-1}$ for $\mathrm{H}^{\prime}$ and 0.77 for J were recorded. Among the species found, the endemic Callisthene inundata O.L. Bueno, A.D. Nilson \& R.G. Magalh. and Picrasma crenata (Vell.) Engl. are included in the list of endangered species. The density found was of 1,557.14 ind ha ${ }^{-1}$. Luehea divaricata Mart. and Lonchocarpus nitidus Benth. showed the highest indexes of importance values. Besides contributing to the knowledge of species distribution and community structure, this study points out the need for conservation of existing native forest remnants.
\end{abstract}

Keywords: alien species, arboreal community, endemic species, riparian vegetation, Taquari-Antas river basin

RESUMO - (Estudo fitossociológico de um remanescente da floresta ribeirinha do rio Taquari, Estado do Rio Grande do Sul, Brasil). Com o objetivo de caracterizar a estrutura da comunidade arbórea de um remanescente de floresta ribeirinha do rio Taquari, foram estabelecidas 42 unidades amostrais de $100 \mathrm{~m}^{2}(10 \times 10 \mathrm{~m})$ e calculados os parâmetros fitossociológicos e índices de diversidade de Shannon (H') e Equabilidade de Pielou (J). Foram amostradas 39 espécies, 21 famílias, 2,83 para H'e 0,77 para J. Dentre as espécies Callisthene inundata O.L. Bueno, A.D. Nilson \& R.G. Magalh. é endêmica, estando, junto com Picrasma crenata (Vell.) Engl., na lista das espécies ameaçadas de extinção. A densidade encontrada foi de 1.557,14 ind. ha ${ }^{-1}$. Luehea divaricata Mart. e Lonchocarpus nitidus Benth. apresentaram os maiores índices de valores de importância. Além de contribuir para o conhecimento da distribuição das espécies e estrutura da comunidade, este estudo alerta para a necessidade de conservação dos remanescentes florestais nativos existentes.

Palavras-chave: bacia hidrográfica do rio Taquari-Antas, comunidade arbórea, espécies endêmicas, espécies exóticas invasoras, vegetação ripária

\section{Introduction}

Vegetation along watercourses and around springs, known as riverine forest, is characterized by the combination of local climate, hydrology, geology and geomorphology factors, as they define landscape and ecological conditions (Rodrigues \& Leitão-Filho 2001). These factors, combined with sedimentation, erosion and flooding, promote floristic diversity and heterogeneity in these formations (AB'Saber 2001, Lima \& Zakia 2001). Due to the importance they represent for the maintenance and development of fundamental environmental processes for the conservation of animal and plant diversity, both terrestrial and aquatic (Lima \& Zachia 2001), it is essential to understand the variation of this vegetation type in a large number of riverine areas and its role in maintaining floral biodiversity.

Due to these environmental characteristics, in Brazil, riparian formations are considered Permanent Preservation Areas (PPA) protected by the Forest Code (Law No. 4.771/65) since September 1965 (Brasil 1965). In 2012, the approval of the new Brazilian Forest Code (Law 12.651) repealed the Law 4.771/65, continuing riverine forest protection (Brasil 2012). Even so, riverine formations are extremely fragmented as a result of human interference, which is responsible, in large part, by species abundance and composition

1. Universidade FEEVALE, Campus II, Rodovia 239, 2755. Novo Hamburgo, 93525-075 RS, Brasil

2. Universidade do Vale do Taquari - Univates, Av. Avelino Tallini, 171, 95900-000 Lajeado, RS, Brasil

3. Universidade do Vale do Taquari - Univates, Museu de Ciências Naturais, Av. Avelino Tallini, 171, 95900-000 Lajeado, RS, Brasil

4. Universidade Federal de Mato Grosso do Sul, Av. Costa e Silva, s/n, 79070-900 Campo Grande, MS, Brasil

5. Corresponding author: fabiane.lucheta@gmail.com 
pattern changes, ecological processes alteration (Rambaldi \& Oliveira 2005) and performance losses in their environmental functions.

Degradation of river and stream banks from Taquari-Antas river Basin (BHRTA), State of Rio Grande do Sul (RS), Brazil, took place as in all other Brazilian river basins, where few fragments remain preserved (Lima et al. 2007, Rempel et al. 2007) today it represents around $26 \%$ of the basin area. These fragments need to be studied in order to know their floristic and community structural diversity to create a baseline for the elaboration and implantation of projects aiming to recover the degraded portions of the riverbanks, favoring remnant fragments connection (Santos 2007). The floristic and structural heterogeneity of these formations, even when they are close to other remnants, have to be considered when elaborating recovering projects, and studies to assess this structure are crucial. Besides, native plant formations are being intensively threatened due to the presence of invasive alien species, probably as a consequence of the fast dispersion of their seeds by flood (Ede \& Hunt 2008), among others. Invasive alien species usually grow rapidly, affecting native species negatively and resulting in habitat alterations and loss of floristic diversity (Leal et al. 2008). Knowing the phytosiocologial parameters of alien species in relation to native species can alert to the need of measures to control such invasions.

Therefore, in order to contribute to information on riverine forests from RS, the objective of this study was to characterize the tree community structure of a riverine forest remnant from Taquari river belonging to BHRTA in the municipality of Muçum, RS, assessing floristic diversity, forest structure and the presence of alien species, besides endangered and endemic species.

\section{Material and methods}

Study Area - The present study was conducted in a riverine forest remnant located on the right bank of Taquari river, Taquari-Antas river Basin, municipality of Muçum, Rio Grande do Sul (figure 1). The fragment, with 3.4 hectares, is located on a river curve where the stream floods the forest during heavy rain periods. The forest remnant appears to be well preserved, making limit with an area of cattle grazing on its upper portion, and an area of agriculture farming and forest vegetation with high incidence of alien species on the sides.
According to the Brazilian Institute of Geography and Statistics (IBGE 2012), the local formation belongs to the Atlantic Forest and is inserted in the Seasonal Deciduous Forest phytoecological formation. The soil is characterized by presenting a complex association of Eutrophic Litholic Soils (IBGE 2017). According to Köppen classification, regional climate is humid subtropical (Cfa) (Peel et al. 2007).

Data Collection - In order to evaluate the arboreal component, a fixed area method was used by systematic distribution of 42 sample units (SU's) of $100 \mathrm{~m}^{2}(10 \times 10 \mathrm{~m})$ distributed at every 20 meters in transects that were parallel to the riverbed and 10 meters away from each other. The first transect was arranged as close as possible to the river bank. In each of the SU's, height was obtained by visual estimation. Then, circumference at breast height $(\mathrm{CBH})$ of all trees with equal or higher than $20 \mathrm{~cm}$ was measured. When specimens had two or more stems, measurement of all stems was conducted if at least one stem had $\mathrm{CBH} \geq 20 \mathrm{~cm}$, then the basal area of each stem was defined and the sum of stems was made.

During sampling, fertile and infertile botanical material was collected for further identification using specific dichotomous keys (Sobral et al. 2013) and consulting experts. If fertile, the material was herborized and incorporated into the HVAT Herbarium of the Universidade do Vale do Taquari - Univates University Center Natural Sciences Museum. Native species nomenclature followed the International Plant Names Index (http://www.ipni.org), while Tropicos from Missouri Botanical Garden (http://www. tropicos.org/) was used for alien species. Families were classified according to the code for Angiosperm Phylogeny Group (APG IV 2016).

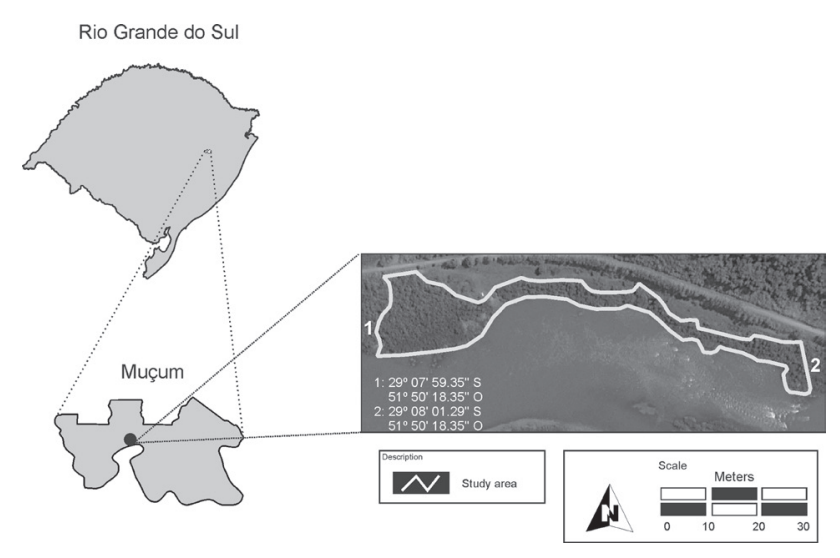

Figure 1. Location of the study area in the municipality of Muçum, State of Rio Grande do Sul, Brazil. 
Data Analysis - For each sampled species, basal area (BA), density (D) absolute (A) and relative (R), frequency (F) A and R, dominance (Do) A and R and importance value index (IVI) were calculated (MullerDombois \& Ellemberg 1974). Arboreal component diversity was estimated by the Shannon Diversity Index (H'), and evenness was evaluated by Pielou's Index (J) using the Past program, 3.0 version (Hammer et al. 2001). In order to estimate expected species richness, "Bootstrap" estimator was used through a presence and absence matrix in the "EstimateS" software (Colwell 2006).

Based on height estimation, individuals were grouped into six height classes (with one meter increment), adapted from Budke et al. (2004) and Lucheta et al. (2015), and the number of individuals per height class was obtained. Similarly, all individuals were grouped into diameter classes (DBH - diameter at breast height) through circumference values conversion, which were obtained during sampling, and grouped into the following classes, adapted from Budke et al. (2004) and Lucheta et al. (2015): 6.0-8.0 cm; 8.1-12.0 cm; 12.1-20.0 cm; 20.1-30.0 cm; $30.1-40.0 \mathrm{~cm} ; 40.1-50.0 \mathrm{~cm} ; 50.1-60.0 \mathrm{~cm}$; 60.1-80.0 cm; 80.1-100.0 cm; 100.1-140.0 cm; $140.1-180.0 \mathrm{~cm} ; 180.1-200.0 \mathrm{~cm}$; $220 \mathrm{~cm}$. Thus, the number of individuals in each diameter class was determined.

Species composition pattern in the fragment was verified by a principal coordinates analysis (PCoA) through Multiv software, using a species abundance matrix without data transformation and chord distance as the similarity measure (Pillar 2009). To verify whether this analysis properly summarized the results, we evaluated Mantel correlation between the distance matrix of the PCoA scores (Euclidean distance) and the distance matrix of the original data (Legendre \& Legendre 1998).

\section{Results}

A total of 654 living arboreal individuals belonging to 39 species, 36 genera and 21 botanical families were sampled. Sampling proved to be enough to represent the community, as the 39 species found in this study accounted for $93 \%$ of the total estimated by "Bootstrap" richness estimator (figure 2).

Families with the highest species richness were Myrtaceae, with eight species (23.08\%), Fabaceae, with seven species (17.95\%) and Euphorbiaceae, with four species $(10.26 \%)$, followed by Moraceae and Sapindaceae, both represented by two species. The remaining 16 families were represented by only one species each.

Of the 39 recorded species, four were alien $(10.3 \%)$, which were represented by 26 individuals $(6.0 \%)$. Among them, Morus nigra L. was the most numerous, with absolute density (AD) of 40.48 ind ha-1 ${ }^{-1}$, followed by Hovenia dulcis Thunb., with 16.67 ind ha ${ }^{-1}$ and also Tecoma stans (L.) Juss. ex Kunth and Psidium guajava L., both with $\mathrm{AD}$ of 2.38 ind ha ${ }^{-1}$ (table 1).

Total basal area, considering the entire sample, was of $16.47 \mathrm{~m}^{2}$, corresponding to a total absolute dominance of $39.23 \mathrm{~m}^{2} \mathrm{ha}^{-1}$. The species with the highest absolute dominance (ADo) were Luehea divaricata Mart. (10.89 $\left.\mathrm{m}^{2} \mathrm{ha}^{-1}\right)$, Terminalia australis Cambess $\left(5.80 \mathrm{~m}^{2} \mathrm{ha}^{-1}\right)$, Myrcia palustris DC. (4.10 $\left.\mathrm{m}^{2} \mathrm{ha}^{-1}\right)$, Lonchocarpus nitidus Benth and Pouteria salicifolia (Spreng) Radlk. (3.84 $\left.\mathrm{m}^{2} \mathrm{ha}^{-1}\right)$ (table 1). The absolute density (AD) of the studied area was estimated in 1,557.1 ind $\mathrm{ha}^{-1}$, the species with the highest AD values were Lonchocarpus nitidus (124

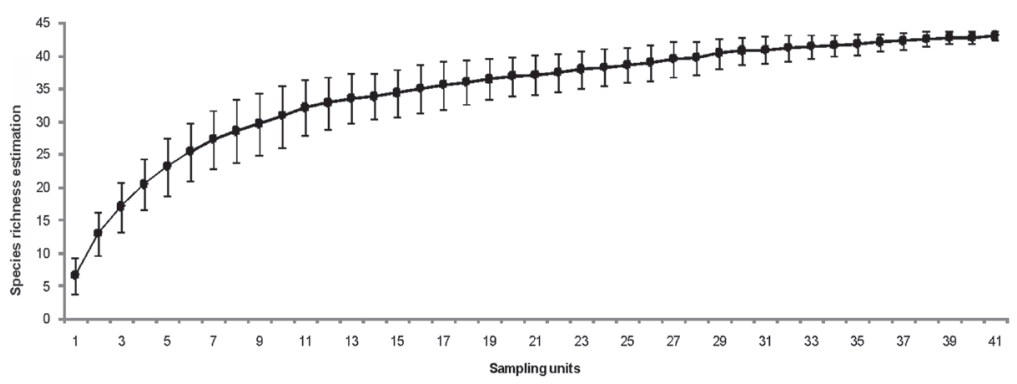

Figure 2. Richness estimative of species in the riverine forest fragment from Taquari river, Muçum/RS, Brazil, by using the "Bootstrap" estimator. Bars indicate standard deviation. 
Table 1. Phytosociological parameters estimated for arboreal species of the riverine forest fragment from Taquari river, Muçum/RS, Brazil, in descending Importance Value Index (IVI) order. Ni: number of individuals. BA: basal area $\left(\mathrm{m}^{2}\right)$. AD: absolute density (ind ha-1). ADo: absolute dominance $\left(\mathrm{m}^{2} \mathrm{ha}^{-1}\right)$. AF: absolute frequency.

\begin{tabular}{|c|c|c|c|c|c|c|c|c|}
\hline Species & Family & Species code & $\mathrm{Ni}$ & BA & ADo & $\mathrm{AD}$ & $\mathrm{AF}$ & IVI \\
\hline Luehea divaricata Mart. & Malvaceae & Ludi & 60 & 4.57 & 10.89 & 142.86 & 57.14 & 15.06 \\
\hline Lonchocarpus nitidus Benth. & Fabaceae & Loni & 124 & 1.61 & 3.84 & 295.24 & 78.57 & 13.36 \\
\hline Myrcia palustris DC. & Myrtaceae & Мypa & 69 & 1.72 & 4.10 & 164.29 & 50.00 & 9.41 \\
\hline Terminalia australis Cambess. & Combretaceae & Teau & 49 & 2.44 & 5.80 & 116.67 & 30.95 & 8.92 \\
\hline Gymnanthes klotzschiana Müll. Arg. & Euphorbiaceae & Gykl & 55 & 0.96 & 2.27 & 130.95 & 59.52 & 7.60 \\
\hline Matayba elaeagnoides Radlk. & Sapindaceae & Mael & 62 & 0.65 & 1.55 & 147.62 & 52.38 & 7.00 \\
\hline Pouteria salicifolia (Spreng.) Radlk. & Sapotaceae & Posa & 27 & 1.61 & 3.84 & 64.29 & 33.33 & 6.25 \\
\hline Calyptranthes concinna DC. & Myrtaceae & Caco & 35 & 0.33 & 0.80 & 83.33 & 35.71 & 4.18 \\
\hline Campomanesia xanthocarpa O.Berg & Myrtaceae & Caxa & 24 & 0.41 & 0.97 & 57.14 & 30.95 & 3.54 \\
\hline Morus nigra L.* & Moraceae & Moni & 17 & 0.35 & 0.83 & 40.48 & 21.43 & 2.60 \\
\hline Eugenia uniflora L. & Myrtaceae & Euun & 16 & 0.15 & 0.36 & 38.10 & 26.19 & 2.39 \\
\hline Parapiptadenia rigida (Benth.) Brenan & Fabaceae & Pari & 12 & 0.14 & 0.33 & 28.57 & 23.81 & 2.04 \\
\hline $\begin{array}{l}\text { Myrceugenia glaucescens (Cambess.) } \\
\text { D.Legrand \& Kausel }\end{array}$ & Myrtaceae & Mygl & 10 & 0.32 & 0.77 & 23.81 & 14.29 & 1.85 \\
\hline Allophylus edulis (A.St.-Hil.) Niederl. & Sapindaceae & Aled & 11 & 0.11 & 0.25 & 26.19 & 21.43 & 1.80 \\
\hline Campomanesia rhombea O.Berg & Myrtaceae & Carh & 9 & 0.13 & 0.31 & 21.43 & 19.05 & 1.64 \\
\hline Myrsine laetevirens (Mez) Arechav. & Primulaceae & Myla & 9 & 0.11 & 0.25 & 21.43 & 16.67 & 1.48 \\
\hline $\begin{array}{l}\text { Vitex megapotamica (Spreng.) } \\
\text { Moldenke }\end{array}$ & Lamiaceae & Vime & 6 & 0.12 & 0.28 & 14.29 & 14.29 & 1.23 \\
\hline Hovenia dulcis Thunb.* & Rhamnaceae & Hodu & 7 & 0.20 & 0.46 & 16.67 & 9.52 & 1.21 \\
\hline Annona neosalicifolia H.Rainer & Annonaceae & Anne & 6 & 0.05 & 0.12 & 14.29 & 9.52 & 0.87 \\
\hline Machaerium stipitatum Vogel & Fabaceae & Mast & 5 & 0.06 & 0.14 & 11.90 & 9.52 & 0.84 \\
\hline Bauhinia forficata Link & Fabaceae & Bafo & 4 & 0.01 & 0.04 & 9.52 & 9.52 & 0.69 \\
\hline $\begin{array}{l}\text { Callisthene inundata O.L.Bueno, A.D. } \\
\text { Nilson \& R.G. Magalh. }\end{array}$ & Vochysiaceae & Cain & 5 & 0.10 & 0.23 & 11.90 & 4.76 & 0.68 \\
\hline Gymnanthes schottiana Müll.Arg. & Euphorbiaceae & Gysc & 4 & 0.05 & 0.12 & 9.52 & 7.14 & 0.65 \\
\hline $\begin{array}{l}\text { Blepharocalyx salicifolius (Kunth) } \\
\text { O.Berg }\end{array}$ & Myrtaceae & Blsa & 4 & 0.04 & 0.10 & 9.52 & 7.14 & 0.63 \\
\hline Machaerium paraguariense Hassl. & Fabaceae & Mapa & 3 & 0.07 & 0.16 & 7.14 & 4.76 & 0.52 \\
\hline Nectandra megapotamica $\mathrm{Mez}$ & Lauraceae & Neme & 2 & 0.04 & 0.10 & 4.76 & 4.76 & 0.42 \\
\hline Trema micrantha (L.) Blume & Cannabaceae & Trmi & 2 & 0.03 & 0.07 & 4.76 & 4.76 & 0.39 \\
\hline $\begin{array}{l}\text { Alchornea triplinervia (Spreng.) Müll. } \\
\text { Arg. }\end{array}$ & Euphorbiaceae & Altr & 2 & 0.02 & 0.05 & 4.76 & 4.76 & 0.37 \\
\hline Guettarda uruguensis Cham. \& Schltdl. & Rubiaceae & Guur & 2 & 0.01 & 0.02 & 4.76 & 4.76 & 0.35 \\
\hline Casearia sylvestris $\mathrm{Sw}$. & Salicaceae & Casy & 2 & 0.01 & 0.02 & 4.76 & 4.76 & 0.35 \\
\hline Inga vera Willd. & Fabaceae & Inve & 2 & 0.01 & 0.02 & 4.76 & 2.38 & 0.24 \\
\hline $\begin{array}{l}\text { Roupala montana var. brasiliensis } \\
\text { (Klotzsch) K.S.Edwards }\end{array}$ & Proteaceae & Romo & 2 & 0.01 & 0.02 & 4.76 & 2.38 & 0.23 \\
\hline Tecoma stans (L.) Kunth * & Bignoniaceae & Test & 1 & 0.01 & 0.02 & 2.38 & 2.38 & 0.18 \\
\hline Maclura tinctoria (L.) D.Don ex Steud. & Moraceae & Mati & 1 & 0.01 & 0.02 & 2.38 & 2.38 & 0.18 \\
\hline Mollinedia schottiana Perkins & Monimiaceae & Mosc & 1 & 0.01 & 0.01 & 2.38 & 2.38 & 0.18 \\
\hline Dalbergia frutescens (Vell.) Britton & Fabaceae & Dafr & 1 & 0.00 & 0.01 & 2.38 & 2.38 & 0.17 \\
\hline Picrasma crenata Engl. & Simaroubaceae & Picr & 1 & 0.00 & 0.01 & 2.38 & 2.38 & 0.17 \\
\hline Psidium guajava L.* & Myrtaceae & Psgu & 1 & 0.00 & 0.01 & 2.38 & 2.38 & 0.17 \\
\hline$\underline{\text { Sapium glandulatum (Vell.) Pax }}$ & Euphorbiaceae & Sagl & 1 & 0.00 & 0.01 & 2.38 & 2.38 & 0.17 \\
\hline TOTAL & & & 654 & 16.47 & 39.23 & 1557.1 & 692.86 & 100 \\
\hline
\end{tabular}

* Exotic and \# endemic species from Taquari-Antas river basin riparian vegetation 
individuals), with 295.24 ind ha ${ }^{-1}$, Myrcia palustris (69 individuals), with 164.29 ind ha-1 Matayba elaeagnoides Radlk. (62 individuals), with 147.62 ind $\mathrm{ha}^{-1}$, Luehea divaricata (60 individuals), with 142.86 ind ha ${ }^{-1}$ and Gymnanthes klotzschiana Müll. Arg., with 55 individuals and density of 130.95 ind ha $^{-1}$ (table 1).

The species with the highest absolute frequency (AF) values were L. nitidus (78.57\%), G. klotzschiana (59.52\%), L. divaricata (57.14\%), M. elaegnoides $(52.38 \%)$ and M. palustris (50\%) (table 1). The highest importance values indice (IVI) were found for L. divaricata (15.06), followed by L. nitidus (13.36), M. palustris (9.41) and T. australis (8.92). Among species, 53.84\% had less than 1.0 IVI (table 1).

Shannon diversity (H') and Pielou's evenness (J) indexes were 2.83 and 0.77 nats ind ${ }^{-1}$, respectively.

Approximately $70 \%$ individuals had heights between 5.0 and 8.9 meters (figure 3), and only $23.3 \%$ were higher than 9.0 meters. Sampled vegetation average DBH was $27 \mathrm{~cm}$, and of the total number of individuals, $65.5 \%$ were in DBH scales corresponding from 6.0 to $30 \mathrm{~cm}$ (figure 4).

The first axis of the principal coordinates analysis (PCoA) explained $23.4 \%$ of the variation of community data, while the second axis explained 16.4\%. The Mantel correlation result ( $\mathrm{r}=0.31$,

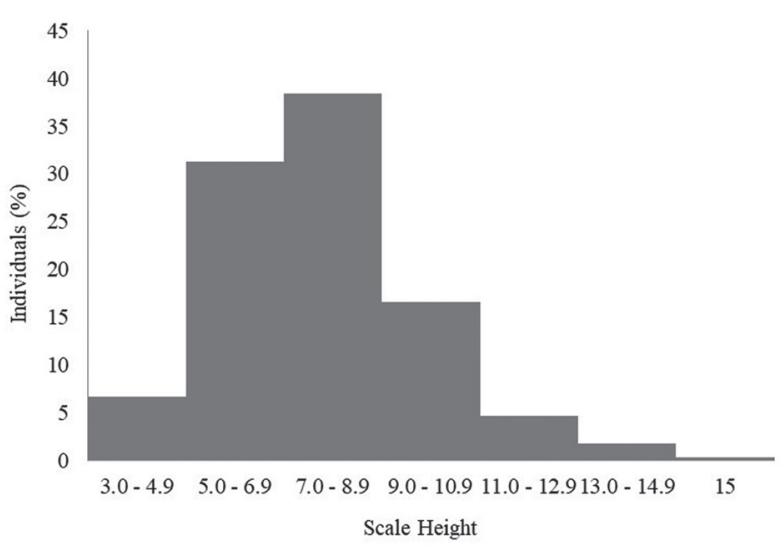

Figure 3. Percentage of individuals sampled in the riverine forest fragment from Taquari river, Muçum/RS, Brazil, by height class.

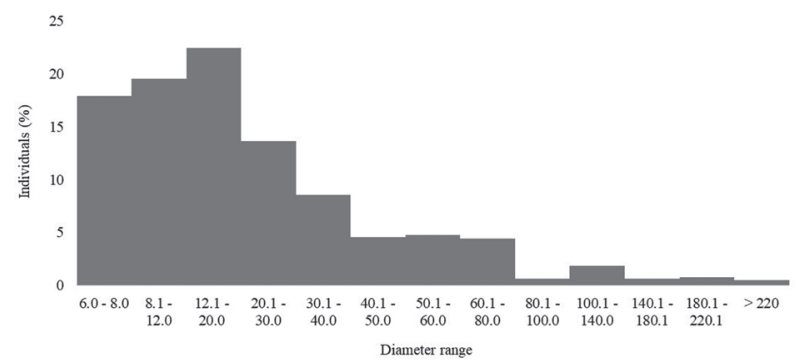

Figure 4. Percentage of individuals sampled in the riverine forest fragment from Taquari river, Muçum/RS, Brazil, by DBH (diameter at breast height).

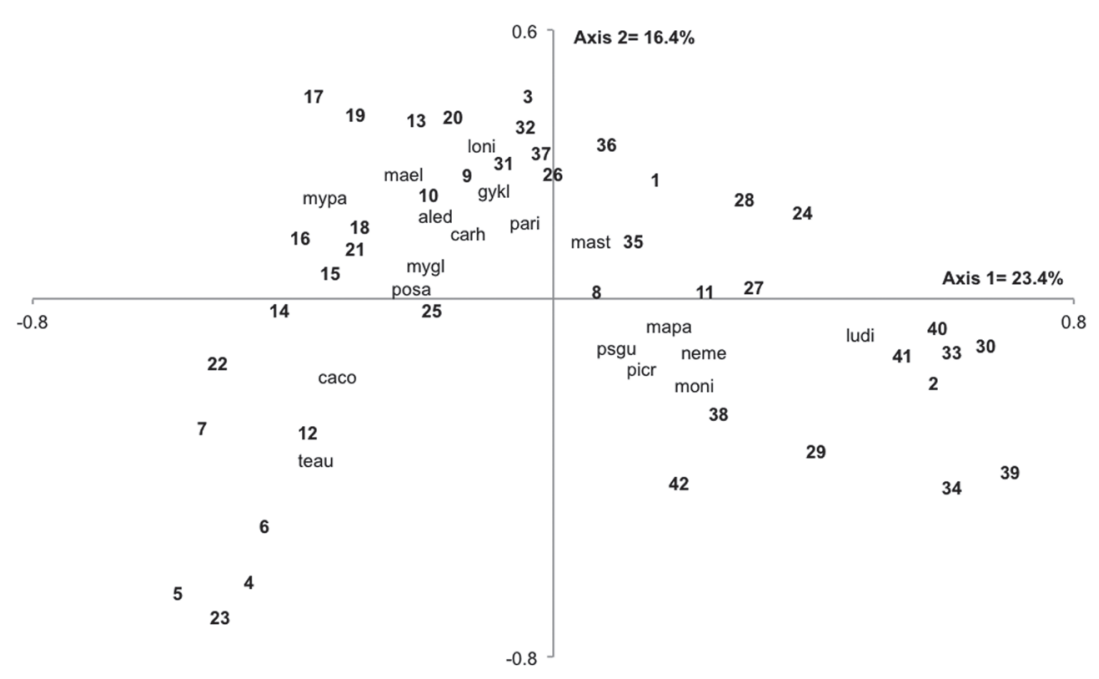

Figure 5. Representation of the first two ordination axes obtained through principal coordinates analysis (PCoA) in a riverine forest fragment from Taquari river, Muçum/RS, Brazil. picr: Picrasma crenata. posa: Pouteria salicifolia. loni: Lonchocarpus nitidus. mael: Matayba elaegnoides. mypa: Myrcia palustris. aled: Allophylus edulis. gykl: Gymnanthes klotzschiana. carh: Campomanesia rhombea. pari: Parapiptadenia rigida. mygl: Myrceugenia glaucescens. mast: Machaerium stipitatum. caco: Calyptranthes concinna. teau: Terminalia australis. mapa: Machaerium paraguariense. psgu: Psidium guajava. neme: Nectandra megapotamica. moni: Morus nigra. ludi: Luehea divaricata. 
$\mathrm{P}=0.001)$ validated the adequability of the PCoA. The analysis of ordination showed that the majority (19) of the closest SU's to the river bank were grouped on the left of the second axis. Among these, eight SU's were grouped due to the presence of Terminalia australis and Calyptranthes concinna DC. and 11 SU's were grouped by Myrcia palustris, Matayba elaeagnoides, Lonchocarpus nitidus, Pouteria salicifolia, Myrceugenia glaucescens (Cambess.) D.Legrand \& Kausel, Campomanesia rhombea O.Berg, Gymnanthes klotschiana, Allophylus edulis (A.St.-Hil.) Niederl. and Parapiptadenia rigida (Benth.) Brenan. Some sampling units were grouped at the right side of the second axis, mainly due to the presence of Luehea divaricata (figure 5), but also related to the presence of Machaerium paraguariense Hassl., Psidium guajava, Nectandra megapotamica (Spreng.) Mez, Picrasma crenata (Vell.) Engl. and Morus nigra.

\section{Discussion}

As in this study, Myrtaceae and Fabaceae (followed by Euphorbiaceae) are also the most representative in other studies conducted in south Brazil riparian forests (Araujo et al. 2004, Brackmann \& Freitas 2013, Lucheta et al. 2015, Mundeleski et al. 2008, SEMA/UFSM-RS 2002, Teixeira et al. 2014).

Although there were few alien species individuals in this fragment, their presence is worrisome (Ziller 2001) as invasive alien plants promote ecosystem impoverishment through biodiversity loss. This loss is the result of native population reduced abundance, which leads to local diversity decrease, impacting on ecosystem structure and functioning (Lowe et al. 2000). Although there are few studies on Taquari river riverine forest, threats of alien species must be evaluated to understand if they are becoming invasive. Lima et al. (2007) has already warned about forest increasing degradation on Taquari river banks, which is likely to favor alien species spread. This was reinforced by Lazzarini et al. (2015), showing that an area invaded by $H$. dulcis had lower species diversity, and this species preferably occupied initial or impacted forests. Similarily, Lucheta et al. (2015) found the same alien species in another fragment of Taquari river riverine forest, as well as other species found here. Therefore, it indicates that these alien species are dispersing along the Taquari river banks and might be threatening biodiversity, although more studies are needed to confirm this statement.
Callisthene inundata, which is endemic to Taquari-Antas river Basin riverine forest (Martinelli \& Moraes 2013), according to the List of Endangered Species of Rio Grande do Sul Flora (2014) and Brazilian Flora 2020, is considered Endangered (EN) as a result of habitat destruction. This is the only species of Vochysiaceae recorded for Rio Grande do Sul, occurring in riverine forest areas subjected to flooding, on stony and shallow soils (Bueno et al. 2000). In addition, Picrasma crenata is considered "Vulnerable" in the Endangered Flora List (Rio Grande do Sul 2014). The two species had lower density and IVI values, reinforcing the importance of preserving this forest remnant and vegetation formation.

The species Luehea divaricata $\left(10.89 \mathrm{~m}^{2} \mathrm{ha}^{-1}\right)$, Terminalia australis $\left(5.80 \mathrm{~m}^{2} \mathrm{ha}^{-1}\right)$, Myrcia palustris $\left(4.10 \mathrm{~m}^{2} \mathrm{ha}^{-1}\right)$, Lonchocarpus nitidus and Pouteria salicifolia reached ADo high values because many individuals had more than one stem, generally consisting of large trees. Lucheta et al. (2015) and Marchi \& Jarenkow (2008) also recorded higher ADo values for L. divaricata, $5.66 \mathrm{~m}^{2} \mathrm{ha}^{-1}$ and $8.60 \mathrm{~m}^{2} \mathrm{ha}^{-1}$, in their studies on riverine forest fragments in RS, although being lower than values found in this study. In the fragment studied by Teixeira et al. (2014) in the same river, L. divaricata had an ADo of only 3.86 $\mathrm{m}^{2} \mathrm{ha}^{-1}$, showing community structure differences, even though fragments were not so distant from each other.

The absolute density (AD) of the studied area was intermediate when compared to the ones recorded by Teixeira et al. (2014) and Lucheta et al. (2015) on the same river banks, using the same sampling methods and criteria for individual inclusion. Teixeira et al. (2014) recorded AD of 2,305.56 ind ha ${ }^{-1}$ in a narrow forest zone, while in the fragment studied by Lucheta et al. (2015) the AD was of 1,373 ind ha ${ }^{-1}$. The comparison of these values reinforces the existence of differences in riparian forests community structure, even when considering the same river. Such changes can be influenced by different factors, as the type of soil, geography and the anthropogenic influence. Considering the studied remnant, the low value recorded for AD may be a consequence of both flood and the strong water stream during flood period, probably responsible for the high incidence of shrub species and tree individuals with many stems, these with large diameter and, in general, lower height.

The species with the highest AD values (Lonchocarpus nitidus, Myrcia palustris, Matayba 
elaegnoides, Luehea divaricata and Gymnanthes klotzschiana) have a different order if compared to ADo. These differences are due to some species with high numbers of lower basal area individuals, while other species had fewer individuals, although having a large DBH or many stems. For example, $L$. nitidus, which had twice the number of individuals in relation to $L$. divaricata, obtained the $5^{\text {th }}$ position if only ADo was considered. Conversely, $L$. divaricata, with fewer individuals, is placed in the $1^{\text {st }}$ position of ADo. Other example is G. klotzschiana and Pouteria salicifolia. In general, G. klotzschiana individuals had fewer stems with smaller circumference. On the other hand, $P$. salicifolia had more stems with larger diameters. High dominance of Terminalia australis and M. palustris was also a result of the large number of individuals and of the number of stems.

Among the $69 \mathrm{M}$. palustris individuals, $41 \mathrm{had}$ more than one stem and eight had more than 10 stems, while an individual reached 22 stems. In the case of T. australis, from the 49 individuals sampled, $40 \mathrm{had}$ more than one stem, and one individual reached 53 stems. By consulting field data obtained in studies by Lucheta et al. (2015) and Teixeira et al. (2014), in fragments that underwent little flood influence, it was found that individuals have few stems. On the other hand, individuals with many stems was found in riparian forests in Rio Grande do Sul (Dorneles et al. 2013, Oliveira et al. 2015), indicating possible adaptation to water strength in flood, since this strategy reduces the exposed surface and allows the water to pass through the stems, preventing their removal. According to Bellingham \& Sparrow (2009), disturbances can stimulate the growth of existing shoots or the emergence of new ones, then promoting high incidence of multiple stems.

Species present in over $50 \%$ of sample units (L. nitidus, G. klotzschiana, L. divaricate, $M$. elaegnoides and $M$. palustris) indicate a broad fragment distribution. Among species with the highest AF values, only $L$. nitidus and $L$. divaricata had higher importance values (IVI). Furthermore, of the total, 22 species occurred in less than $10 \%$ of SU's, corresponding to more than $50 \%$ of species with low frequency. Other studies in riparian forest fragments in Rio Grande do Sul also reported few species with high frequency value. Among the 29 species found by Marchi \& Jarenknow (2008) in a riverine forest fragment along Camaquã river, four had frequency higher than $75 \%$, and all other species occurred in less than $50 \%$ of SU's, of which five species $(17.25 \%)$ were only found in one sampling unit. In Lucheta et al. (2015), L. divaricata, Allophylus edulis and Trichilia clausseni C.DC. occurred in over 50\% of SU's, and most species (85.5\%) were recorded in less than $20 \%$ of sampling units. These results show the diversity in riparian forests, as, for example, T. clausseni, with high frequency in Lucheta et al. (2015), was not recorded in the area of the present study, both located on the same riverbed. The variation on species diversity, distribution and abundance of tropical plant communities can be influenced by different factors that vary from biogeographic to microenvironmental scale (Zuquim et al. 2007). For Svenning (1999), altitude, slope, topographic position, drainage and soil fertility are among the factors determining species distribution. Cámara-Leret et al. (2017) showed, for example, that all palm species had differences in distribution along soil nutrient gradients in Western Amazon. In the case of the present study, it is likely that flood, associated to water force, infuences species selection, distribution and abundance. The low declivity and the water flow favor periodic flood and prolonged flood that can influence the vegetation strata (De Morais et al. 2013). For the plant community composition and structure of four phytophisionomies in Pantanal of Poconé, Mato Grosso, flood pulse could be responsible for habitat and niche formation, favoring spatial heterogeneity and determining species distribution and the formation of a landscape mosaic (De Morais et al. 2013).

Luehea divaricata was the species with the highest IVI in the forest remnant, however its presence was higher in plots that were further from the riverbank. Its main habitats are riparian forests or hillsides, and this species is important for degraded areas recovery, as it tolerates short or long-term periodic flooding, low temperatures and has quick growth, besides tolerating shading when young (Gris et al. 2012). Furthermore, the fragment was mainly represented by Lonchocarpus nitidus, Myrcia palustris, Terminalia australis, Gymnanthes klotzschiana, Matayba elaegnoides, Pouteria salicifolia, Calyptranthes concinna and Campomanesia xanthocarpa, which showed the highest values of IVI and are characteristic species of riparian forests. The species with the second highest IVI was L. nitidus, a common species in riparian forests, which can be used for riparian forest recovery (Silva \& Tozzi 2012). The occurrence of deciduous hygrophytes species, adapted to alluvial environments was also recorded, such as $L$. divaricata, Vitex megapotamica (Spreng.) Moldenke, Inga vera Willd. and G. klotzschiana (IBGE 2012). 
Shannon diversity and Pielou's evenness indexes presented slightly lower values than those reported in other studies in the same river, probably reflecting the existence of fewer species with unequal number of individuals. Lucheta et al. (2015), in the municipality of Lajeado, found a Shannon index of 3.39 nats ind ${ }^{-}$ ${ }^{1}$ and Pielou's index of 0.82. Teixeira et al. (2014), also in the municipality of Lajeado, found 3.09 nats ind ${ }^{-1}$ for Shannon index and 0.84 for the evenness index. On the other hand, some studies had lower indexes, as was the case of the study by Jarenkow \& Waechter (2001) in a seasonal forest from Rio Grande do Sul, whose indexes were 2.24 nats $^{-1} \mathrm{~d}^{-1}$ for $\mathrm{H}^{\prime}$ and 0.56 for J. Moreover, the study by Damaceno-Junior et al. (2005), conducted in a riverine forest of Paraguay river, State of Mato Grosso do Sul, recorded H' $=2.7$ when sampling an arboreal community with diameter at breast height of less than $15 \mathrm{~cm}$, which is lower but close to the values of the present study.

L. divaricata and Hovenia dulcis had 37 and 4 individuals, respectively, with $>10$ meters. The forest studied had few trees with large DBH, as the majority of trees sampled were below $30 \mathrm{~cm}$. This, along with multiple stems, is a strategy to resist to water flow during flood periods.

The principal coordinates analysis (PCoA) indicated higher similarity in sampling units that were slightly further from the riverbank. The same was found by Campos \& Landgraf (2001) in Minas Gerais, where L. divaricata was present only in the furthest parts of the lake, probably because this species does not tolerate wet soils. According to DamascenoJunior (2005), flood levels tend to determine the species exchange degree between dry and flooded environments.

The floristic composition found in the area of the present study is somehow similar to the recorded in other studies carried out in riverine forests in Rio Grande do Sul and Santa Catarina (Araujo et al. 2004, Avila et al. 2011, Brackmann \& Freitas 2013, Schneider \& Rocha 2014, Teixeira et al. 2014, Lucheta et al. 2015). However, it differs on the way species are organized. As seen by Durigan et al. (2000), riparian forests show a combination of arboreal species with wide and narrow distribution, according with the phytogeographic unit where they are inserted, demonstrated in the present study as the record of one endemic endangered species. These results highlight thus the importance of the studied forest remnant and the need to adopt measures for its conservation and understanding the role of alien species, if they are transient or if they will become invasive.

\section{Acknowledgement}

The authors thank FAPERGS for financing the research and for the scholarship granted to the second and third author (PROCOREDES VIII $n^{\circ}$ 012/2011 - Process 12/0014-0). The authors also thank Leticia Rodrigues Vieira and Norton Dametto for the assistance in all activities and Martin Grings for helping in the identification of some species. Natália Mossmann Koch thanks Capes for her post-doctoral grant (PNPD).

\section{Literature cited}

Ab'Saber, A.N. 2001 O suporte geo-ecológico das florestas beiradeiras (ciliares). In: R.R. Rodrigues \& H.F. Leitão Filho (eds.). Matas ciliares: Conservação e recuperação. Editora da Universidade de São Paulo, São Paulo. pp. 15-25.

Araujo, M.M., Longhi, S.J., Brena, D.A., Barros, P.L.C. \& Franco, S. 2004. Análise de agrupamento da vegetação de um fragmento de floresta estacional decidual aluvial, Cachoeira do Sul, RS, Brasil. Ciência Florestal 14:133-147.

Avila, A.L., Araujo, M.M., Longhi, S.J. \& Gasparin, E. 2011. Caracterização da vegetação e espécies para recuperação de mata ciliar, Ijuí, RS. Ciência Florestal 21: 251-260.

Bellingham, P.J. \& Sparrow, A.D. 2009. Multi-stemmed trees in montane rain forests: their frequency and demography in relation to elevation, soil nutrients and disturbance. Journal of Ecology 97: 472-483.

Brackmann, C.E. \& Freitas, E.M. 2013. Florística arbórea e arbustiva de um fragmento de Mata Ciliar do arroio Boa Vista, Teutônia, RS, Brasil. Hoehnea 40: 365-372.

Brasil. 2015. Lei $\mathrm{n}^{\circ}$ 4.771, de 15 de setembro de 1965. Institui o novo Código Florestal. Available in http:// www.planalto.gov.br/ccivil_03/Leis/L4771.htm (access in 13-XI-2015).

Brasil. 2015. Lei no 12.651, de 25 de maio de 2012. Dispõe sobre a proteção da vegetação nativa Available in http:// www.planalto.gov.br/ccivil 03/ ato2011-2014/2012/ lei/112651.htm (access in 18-VIII-2015).

Budke, J.C., Giehl, E.L.H., Athayde, E.A., Eisinger, S.M. \& Záchia, R.A. 2004. Florística e fitossociologia do componente arbóreo de uma floresta ribeirinha, Arroio Passo das Tropas, Santa Maria, RS, Brasil. Acta Botanica Brasilica 18: 581-589.

Bueno, O.L., Nilson, A.D. \& Magalhães, R.G. 2000. Callisthene inundata nova espécie de Vochysiaceae e primeiro registro desta família no Estado do Rio Grande do Sul. Iheringia Série Botânica 53: 101-116.

Byng, J.W. et al. 2016. An update of the Angiosperm Phylogeny Group classification for the orders and families of flowering plants: APG IV. Botanical Journal of the Linnean Society 181: 1-20. 
Cámara-Leret, R., Tuomisto, H., Ruokolainen, K., Balslev, H. \& Kristiansen, S.M. 2017. Modelling responses of western Amazonian palms to soil nutrients. Journal of Ecology 105: 367-381.

Campos, J.C. \& Landgraf, P.R.C. 2001. Análise da regeneração natural de espécies florestais em matas ciliares de acordo com a distância da margem do lago. Ciência Florestal 11: 43-151.

Colwell, R.K. 2006. EstimateS: Statistical estimation of species richness and shared species from samples. Version 8. Available in http://purl.oclc.org/estimates (access in 29-II-2016).

Damasceno-Junior, G.A., Semir, J., Santos, F.A.M. \& Leitão-Filho, H.F. 2005. Structure, distribution of species and inundation in a riparian forest of Rio Paraguai, Pantanal, Brazil Flora 200:119-135.

Morais, R.F., Da Silva, E.C.S., Metelo, M.R.L. \& Morais, F.F. 2013. Floristic composition and structure of the plant community of different phytophysiognomies in the Pantanal of Poconé, Mato Grosso. Rodriguésia 64: 775-790.

Dorneles, L.P.P., Gutierres, V.S., Bianchin, A. \& Telöken, F. 2013. Estrutura do componente arbóreo de uma floresta ribeirinha da Planície Costeira do Rio Grande do Sul, Brasil. Iheringia Série Botânica 68: 37-46.

Durigan, G., Rodrigues, R.R. \& Schiavini, I. 2000. A heterogeneidade ambiental definindo a metodologia de amostragem da floresta ciliar. In: R.R. Rodrigues, \& H.F. Leitão Filho (eds.). Matas ciliares: Conservação e recuperação. Editora da Universidade de São Paulo, São Paulo. pp. 159-167.

Ede, F.J. \& Hunt, T.D. 2008. Habitat Management Guide. Riparian: Weed Management in Riparian Areas: South-eastern Australia. CRC for Australian Weed Management, Adelaide, pp 4-8.

Gris, D., Temponi, L.G. \& Marcon, T.R. 2012. Native species indicated for degraded area recovery in Western Paraná, Brazil. Revista Árvore 36: 113-125.

Hammer, O., Harper, D.A.T. \& Ryan, P.D. 2001. PAST: Paleontological Statistics Software Package for Education and Data Analysis. Palaeontologia Electronica 4: 1-9.

IBGE (Instituto Brasileiro de Geografia e Estatística). 2012. Manual técnico da vegetação brasileira. Manuais Técnicos em Geociências, n. 1, Rio de Janeiro.

IBGE (Instituto Brasileiro de Geografia e Estatística). 2017. Mapa exploratório de solos do Rio Grande do Sul. Available in ftp://geoftp.ibge.gov.br/informacoes ambientais/pedologia/mapas/unidades_da_federacao/ rs pedologia.pdf (access in 11-III-2017).

Jarenkow, J.A. \& Waechter, J.L. 2001. Composição, estrutura e relação florística do componente arbóreo de uma floresta estacional no Rio Grande do Sul, Brasil. Revista Brasileira de Botânica 24: 263-272.
Lazzarin, L.C., Silva, A.C., Higuchi, P., Souza, K., Perin, J.E. \& Cruz, A.P. 2015. Invasão Biológica por Hovenia Dulcis Thunb. em Fragmentos Florestais na Região do Alto Uruguai, Brasil. Revista Árvore 39: 1007-1017.

Leal, G., Mota, A.C.D., Freitas, C., Morgado, K. \& Moreira, I. 2008. Selection of Techniques. In: D. Arizpe, A. Mendes, \& J.E. Rabaça (eds.). Sustainable Riparian Zones: A Management Guide. Generalitat Valenciana, Portugal, pp 177-191.

Legendre, P. \& Legendre, L. 1998. Numerical Ecology, Second Edition. Elsevier, Amsterdam.

Lima, D.F.B., Rempel, C. \& Eckhardt, R.R. 2007. Análise Ambiental da Bacia Hidrográfica do Rio Taquari Proposta de Zoneamento Ambiental. Geografia 16: 51-78.

Lima, W.P. \& Zakia, M.J.B. 2001. Hidrologia de matas ciliares. In: R.R. Rodrigues, \& H.F. Leitão Filho (eds.). Matas ciliares: Conservação e recuperação. Editora da Universidade de São Paulo, São Paulo. pp. 33-44.

Lowe, S., Browne, M., Boudjelas, S. \& De Poorter, M. 2000. Global Invasive Species Database. Available in http://www.issg.org/database/species/reference files/100English.pdf (access in 09-III-2016).

Lucheta, F., Teixeira, M., Koch, N.M. \& Freitas, E.M. 2015. Estrutura da comunidade arbórea de um fragmento de floresta ribeirinha do rio Taquari, Lajeado, Rio Grande do Sul, Brasil. Iheringia Série Botânica 70: 343-355.

Martinelli, G. \& Moraes, M. 2013. Livro Vermelho da Flora do Brasil. 1 ed. Instituto de Pesquisas do Jardim Botânico do Rio de Janeiro, Rio de Janeiro.

Marchi, T.C. \& Jarenkow, J.A. 2008. Estrutura do componente arbóreo de mata ribeirinha no rio Camaquã, município de Cristal, Rio Grande do Sul, Brasil. Iheringia Série Botânica 63: 241-248.

Mueller-Dombois, D. \& Ellemberg, H. 1974. Aims and methods of vegetation ecology. John Wiley, New York.

Mundeleski, E., Schmitz, J.A.K. \& Biondo, E. 2008. Estudo Ambiental da microbacia do arroio Jacarezinho (Nova Bréscia e Encantado, RS) com ênfase na mata ciliar e na qualidade da água. Caderno de Pesquisa, Série Biologia 20: 44-61.

Oliveira, M.L.A.A., Grings, M., Richter, F.S. \& Backes, A.R. 2015. Composição, estrutura e fatores edáficos condicionantes da distribuição das espécies do componente arbóreo em floresta ribeirinha do rio Ibirapuitã, Bioma Pampa. Iheringia Série Botânica 70: 245-263.

Peel, M.C., Finlayson, B.L. \& McMahon, T.A. 2007. Updated world map of the Köppen-Geiger climate classification. Hydrology and Earth System Sciences 11: 1633-1644.

Pillar, V.D. 2009. Multiv: Multivariate exploratory analysis: randomization testing and bootstrap resampling 2.63 beta. Available in http://ecoqua.ecologia.ufrgs.br. (access in 29-II-2016). 
Rambaldi, D.M. \& Oliveira, D.A.S. (orgs.). 2005. Fragmentação de ecossistemas: causas, efeitos sobre a biodiversidade e recomendações de políticas públicas. 2 ed. MMA/SBF, Brasília.

Rempel, C., Périco, E. \& Eckhardt, R.R. 2007. Zoneamanento econômico-ambiental do Vale do Taquari. Editora Univates, Lajeado.

Rio Grande do Sul. 2016. Decreto Estadual no 52.109, de 19 de dezembro de 2014. Declara as espécies da flora nativa ameaçada de extinção no Estado do Rio Grande do Sul. Available in http://www.fzb. rs.gov.br/upload/20141222103647doe.pdf (access in 10-III-2016).

Rodrigues, R.R. \& Leitão-Filho, H.F. 2001. Matas Ciliares: Conservação e Recuperação. 2 ed. FAPESP EDUSP, São Paulo.

Rodrigues, R.R. \& Nave, A.G. 2001. Heterogeneidade florística da floresta ribeirinha $I n$ : R.R. Rodrigues \& H.F. Leitão Filho (eds.). Matas ciliares: Conservação e recuperação. Editora da Universidade de São Paulo, São Paulo. pp. 45-72.

Santos, R.F. 2007. Vulnerabilidade Ambiental. MMA, Brasília.

Silva, M.J. \& Tozzi, A.M.G.A. 2012. Revisão taxonômica de Lonchocarpus s. str. (Leguminosae, Papilionoideae) do Brasil. Acta Botanica Brasilica 26: 357-377.
Schneider, G. \& Rocha, F.S. 2014. Levantamento florístico e fitossociológico do componente arbóreo de um fragmento de Floresta Estacional Decidual em São Miguel do Oeste, Santa Catarina. Revista Biotemas 27: 43-55.

SEMA/UFSM-RS (Secretaria Estadual do Meio Ambiente). 2002. Relatório Final do Inventário Florestal Contínuo do Rio Grande do Sul. Porto Alegre, Santa Maria.

Sobral, M., Jarenkow, J.A., Brack, P., Irgang, B., Larocca, J. \& Rodrigues, R.S. 2013. Flora arbórea e arborescente do Rio Grande do Sul, Brasil. Editora Rima, São Carlos.

Svenning, J-C. 1999. Microhabitat specialization in a species-rich palm community in Amazonian Ecuador. Journal of Ecology 87: 55-65.

Teixeira, M., Pavan, A.M., Scherer, L.C., Nicolini, G. \& Freitas, E.M. 2014. Estrutura da comunidade arbórea de um fragmento de mata ciliar do rio Taquari, Colinas, Rio Grande do Sul. Revista Jovens Pesquisadores 4: 19-31.

The International Plant Names Index. 2012. Available in http://www.ipni.org (access in 28-II-2018).

Tropicos. 2016. Missouri Botanical Garden. Available in http://www.tropicos.org. (access in 10-III-2016).

Ziller, S.R. 2001. Plantas exóticas invasoras: a ameaça da contaminação biológica. Ciência Hoje 30: 77-79.

Zuquim, G., Costa, F.R.C. \& Prado, J. 2007. Fatores que determinam a distribuição de espécies de pteridófitas da Amazônia Central. Revista Brasileira de Biociências 5: $360-362$. 